\title{
Tracing Marine Processes in the Southern Ocean by Means of Naturally Occurring Radionuclides
}

\author{
Claudia Hanfland · Walter Geibert · Ingrid Vöge \\ Alfred Wegener Institute for Polar and Marine Research, Am Handelshafen 12, 27570 Bremerhaven, Germany, <chanfland@awi-bremerhaven.de>
}

\begin{abstract}
Members of the naturally occurring decay series are found throughout the world's oceans, though in activities that vary by several orders of magnitude within the same decay series. They can be distinguished on the basis of their overall reactivity - e.g., adsorption or incorporation - with particles. Physical and biogeochemical processes in the water column, and close to the sedimentwater interface, lead to fractionation of mother and daughter nuclides and hence create disequilibria in the decay series. These disequilibria have become powerful tools in the study of marine processes. In order to illustrate their use in marine sciences, three examples are presented for the Atlantic sector of the Southern Ocean. For the group of particle-reactive radionuclides, the distribution of the short-lived isotope ${ }^{234} \mathrm{Th}$ (half-life 24.1 days) is used as a measure of export fluxes from the photic layer. ${ }^{228} \mathrm{Ra}$ and ${ }^{227} \mathrm{Ac}$ (halflives 5.8 and 21.7 years, respectively), belong to the more soluble nuclides. In contrast to ${ }^{234} \mathrm{Th}$, they are hardly found in the particulate fraction of a sea water sample but instead exist in the dissolved state. ${ }^{228} \mathrm{Ra}$ is indicative of shelf water input while ${ }^{227} \mathrm{Ac}$ is a tracer for upwelling deep water masses.
\end{abstract}

\section{Introduction}

Since the discovery of radioactivity, unstable isotopes have become the basis of geochronology, a tool critical to modern geology. While common rock dating methods mostly rely on the long-lived members of the naturally occurring decay series ${ }^{238} \mathrm{U}-{ }^{206} \mathrm{~Pb},{ }^{235} \mathrm{U}-{ }^{207} \mathrm{~Pb}$ and ${ }^{232} \mathrm{Th}-{ }^{208} \mathrm{~Pb}$ (half-lives $4.47 \times 10^{9}, 7 \times 10^{8}$ and $14 \times 10^{9}$ years, respectively), marine processes take place on much shorter time scales. In view of the overturning rate of the ocean in the order of 1000-2 000 years (Broecker and Peng 1982), the short-lived intermediate daughter products are of great importance.

Besides the half-life, the chemical and biochemical reactivity of a given element in sea water its tendency to get adsorbed onto particle surfaces or its participation in biological processes - is important in marine applications. While Uranium or Radium exist mostly in the dissolved state, other elements like Thorium, Polonium or Protactinium are more adsorption-prone and can hence effectively be removed from the water column by attaching to particles that subsequently sink. Polonium is also known to be incorporated into organic tissue (Fisher et al. 1983) and can be removed from the marine environment via this mechanism. From the viewpoint of application, the difference in particle-reactivity can be used as criteria for the distinction between a group of radionuclides used for water mass studies and those more applicable to particle studies. While rocks unaffected by weathering represent a closed system with regard to the short-lived radionuclides - which are consequently found to be in secular equilibrium with their precursor isotopes - this is not the case for the marine system. Instead, strong partitioning of the isotopes can occur within a single decay series between the dissolved and the particulate phase. This results in conspicuous radioactive disequilibria in any given parent-daughter pair.

Uranium, Radium isotopes as well as ${ }^{232} \mathrm{Th}$ enter the ocean mostly by fluvial input. In general, concentrations of radionuclides in the oceans are considerably lower than in both their source rocks on land and in river water (Table 8.1-1). This finding is attributable to various processes taking place during the mobilization and the transport from the source area to the ocean. Estuaries are known to act as filters for radioisotopes (Moore 1992) and have a considerable influence on the budget of an element in ocean water. While Uranium is about a thousand times more abundant in sea water than gold, the majority of the intermediate decay products are only present in trace amounts. For example, the total amount of ${ }^{227} \mathrm{Ac}$, one of the rarest isotopes in the world's oceans, is estimated to be less than $20 \mathrm{~kg}$.

Table 8.1-1. Average concentrations of selected radionuclides in rocks, river and sea water. Data from Faure (1986), The Open University (1989), Krishnaswami (2001) and Geibert (2002)

\begin{tabular}{|l|l|l|l|c|}
$\begin{array}{l}\text { Element } \\
(\mathrm{ppm})\end{array}$ & Basalt & $\begin{array}{l}\text { Granitic } \\
\text { rocks }\end{array}$ & River water & Sea water \\
\hline $\mathrm{U}$ & 0.43 & 4.8 & $0.1-1$ & 0.0032 \\
$\mathrm{Th}$ & 1.6 & 21.5 & 0.01 & $1 \times 10^{-5}$ \\
$\mathrm{~Pb}$ & 3.7 & 23 & Highly variable & $5 \times 10^{-7}$ \\
${ }^{226} \mathrm{Ra}$ & $\mathrm{a}$ & $\mathrm{a}$ & Highly variable & $7 \times 10^{-11}$ \\
${ }^{227} \mathrm{Ac}$ & $\mathrm{a}$ & $\mathrm{a}$ & No data & $<20 \mathrm{~kg}$ \\
\hline
\end{tabular}

a Isotopes are in radioactive equilibrium with their precursor isotopes in rocks unaffected by weathering processes. 
Owing to their low activities, determination of radionuclide concentrations in the marine environment is commonly performed with $\alpha$-, $\beta$ - and $\gamma$-counting in combination with large volume sampling. However, the ongoing improvement of measurement techniques, especially in the field of mass spectrometry, constantly brings more radionuclides into a new or wider field of application.

The Southern Ocean represents a key area in today's climate system and is often regarded as an early-warning system for the world's climate as a whole. However, the polar environment and its feed-back mechanisms are far from being completely understood. Any precise reconstruction of the palaeoclimatic conditions as well as reliable predictions of future trends involve both a close investigation of the processes and interactions that govern the modern climate, and with it the Southern Ocean, today. In this respect, radionuclide studies can yield valuable additional insights as their specific half-lives provide valuable time-relevant information.

In the following, three examples from the Southern Ocean are given to illustrate the application of radionuclides in the study of marine processes. We show their use regarding particle transport and movement of water masses.

\section{Methods}

For the analysis of ${ }^{234} \mathrm{Th}, 201$ samples of sea water were filtered $(1 \mu \mathrm{m})$, followed by $\mathrm{MnO}_{2}$-precipitation in the supernatant. to remove Thorium from solution. The precipitate was filtered, too, and both the particulate and the dissolved fraction were analyzed for their ${ }^{234} \mathrm{Th}$ activity via $\beta$-counting.

${ }^{228} \mathrm{Ra}$ and ${ }^{227}$ Ac were collected by pumping several hundred liters of sea water through two $\mathrm{MnO}_{2}$-coated filter cartridges put in series. These were either connected to the ship's sea water supply or loaded on time-programmed filtration units. For the determination of the ${ }^{228} \mathrm{Ra}$ activity, the filter cartridges were combusted in a muffle furnace and the ${ }^{228} \mathrm{Ra}$ content of the ash either determined directly by $\gamma$-spectrometry or via a modified version of the ${ }^{228}$ Th-ingrowth method (Moore 1972; Hanfland 2002). ${ }^{227} \mathrm{Ac}$ was brought into solution through leaching of the filter cartridges. After purification by ion column chemistry, its activity was plated on silver planchets and determined via its short-lived daughter ${ }^{227}$ Th by $\alpha$-spectrometry. A full description of all the methods used is given in Rutgers van der Loeff and Moore (1999).

\section{${ }^{234}$ Th As an Indicator of Export Production}

${ }^{234} \mathrm{Th}$ (half-life 24.1 days; Table $8.1-2$ ) is selected as representative of a highly particle-reactive element. It is produced in the water column through the decay of ${ }^{238} \mathrm{U}$, an
Table 8.1-2. The ${ }^{238} \mathrm{U}_{-}{ }^{206} \mathrm{~Pb},{ }^{235} \mathrm{U}-{ }^{207} \mathrm{~Pb}$ and ${ }^{232} \mathrm{Th}-{ }^{208} \mathrm{~Pb}$ decay series with decay schemes of the daughter nuclides presented in this study and their corresponding half-lives

\begin{tabular}{|c|c|c|c|c|c|c|}
\hline $\begin{array}{l}{ }^{238} \mathrm{U} \\
4.5 \times 10^{9} \mathrm{yr} \\
{ }^{235} \mathrm{U} \\
7.04 \times 10^{8} \mathrm{yr} \\
{ }^{232} \mathrm{Th} \\
1.4 \times 10^{10} \mathrm{yr}\end{array}$ & $\Rightarrow \Rightarrow$ & $\begin{array}{l}{ }^{234} \mathrm{Th} \\
24.1 \mathrm{~d} \\
{ }^{231} \mathrm{~Pa} \\
{ }^{32.800 \mathrm{yr}} \\
{ }^{228} \mathrm{Ra} \\
{ }^{5.75} \mathrm{yr}\end{array}$ & $\begin{array}{l}\Rightarrow \\
\Rightarrow\end{array}$ & $\begin{array}{l}{ }^{206} \mathrm{~Pb} \\
\text { stable } \\
{ }^{227} \mathrm{Ac} \\
21.8 \mathrm{yr} \\
{ }^{228} \mathrm{Th} \\
1.91 \mathrm{yr}\end{array}$ & $\begin{array}{l}\Rightarrow \Rightarrow \\
\Rightarrow \Rightarrow\end{array}$ & $\begin{array}{l}{ }^{207} \mathrm{~Pb} \\
\text { stable } \\
{ }^{208} \mathrm{~Pb} \\
\text { stable }\end{array}$ \\
\hline
\end{tabular}

$\rightarrow$ decay step to next daughter nuclide; $\Rightarrow \Rightarrow$ one or more decay steps have been omitted.

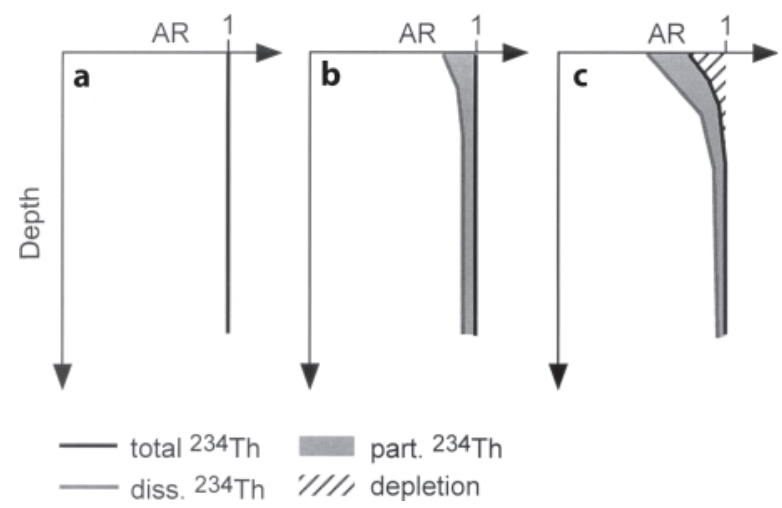

Fig. 8.1-1. Depth profiles showing the partitioning of ${ }^{234} \mathrm{Th}$ between the dissolved and particulate phase. Situation $\mathbf{a}$ in an ideal ocean without particles; $\mathbf{b}$ in early spring before the onset of primary production; c after development of plankton blooms. Profiles b and c stylized from data after Rutgers van der Loeff and Berger (1991). $A R:{ }^{234} \mathrm{Th} /{ }^{238} \mathrm{U}$ activity ratio

isotope with conservative behaviour that is evenly distributed throughout the water column. Its activity is related to salinity by ${ }^{238} \mathrm{U}\left[\mathrm{dpm} \mathrm{^{-1 }}\right]=0.0704$ Salinity (Rutgers van der Loeff et al. 1997). In an ideal ocean without any particles, the activity between parent and daughter nuclide can be taken as unity, a scenario that is best matched in the open ocean during early spring before the onset of plankton blooms (Fig. 8.1-1a). With only few particles present or at the beginning of a bloom, the ${ }^{234} \mathrm{Th}$ inventory is partitioned between the dissolved and the particulate phase but still sums up to unity (Fig. 8.1-1b). Subsequent sinking of particles leads to export not only of organic matter but also of a fraction of ${ }^{234} \mathrm{Th}$ (Fig. 8.1-1c). Hence, the depletion of ${ }^{234} \mathrm{Th}$ in the upper water column with respect to its parent nuclide ${ }^{238} \mathrm{U}$ can be taken as a measure of export production from the euphotic zone (Coale and Bruland 1985). From this depletion, the export of other constituents like organic carbon or biogenic silica can be calculated assuming the ratio of this material to particulate ${ }^{234} \mathrm{Th}$ has been determined. Once the particle production stops and the remaining particulate fraction sinks to deeper water layers, ${ }^{234} \mathrm{Th}$ can grow back into equilibrium with its precursor. 


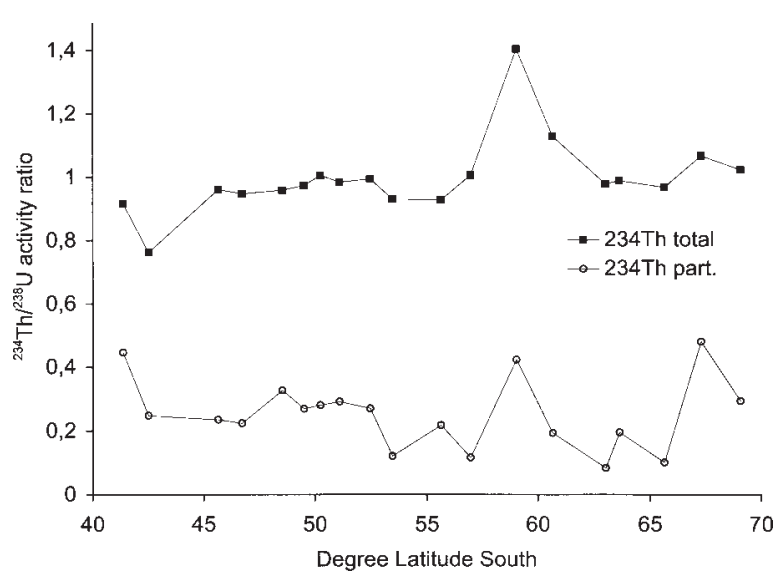

Fig. 8.1-2. ${ }^{234} \mathrm{Th} /{ }^{238} \mathrm{U}$ activity ratios during austral spring (RV "Polarstern" expedition ANT-XV/2). For sample processing and analysis of ${ }^{234} \mathrm{Th}$ see Rutgers van der Loeff and Moore (1999)

Figure 8.1-2 shows the particulate and total ${ }^{234} \mathrm{Th}$ content of surface water samples collected during austral spring (November 1997) on a N-S transect across the Antarctic Circumpolar Current (ACC) between Cape Town and Neumayer Base at Atka Bay. Originally, ${ }^{234} \mathrm{Th}$ was determined on this transect as natural yield tracer for the analysis of the ${ }^{230} \mathrm{Th}$ and ${ }^{231} \mathrm{~Pa}$ activities (Walter et al. 2001).

The data correspond well with the situation given in Fig. 8.1-1b: ${ }^{234} \mathrm{Th}$ is mostly in secular equilibrium with ${ }^{238} \mathrm{U}$. Considerable export can only be observed at the approximate position of the Subtropical Front, where primary production seemed to start earlier than further south. The sample at $59^{\circ} \mathrm{S}$ contained a lot of krill. This is probably the reason for the high total ${ }^{234} \mathrm{Th}$ activity caused by its accumulation in the food chain.

With the development of strong blooms, clear export signals could be observed on the same transect later in season in a subsequent year (March 1999) with highest depletion coinciding with the ACC frontal systems (Usbeck et al.2002). The repeated determination of ${ }^{234} \mathrm{Th}$ on vertical profiles yielded evidence for the productive nature of the ACC fronts and the related export production.

\section{${ }^{228} \mathrm{Ra}$ As a Tracer for Shelfwater Advection}

${ }^{228} \mathrm{Ra}$ (half-life 5.75 years; Table $8.1-2$ ) has been widely used as a tracer for water masses originating from the continental shelves (e.g., Kaufmann et al. 1973; Reid et al. 1979; Rutgers van der Loeff et al. 1995). It is a daughter product of ${ }^{232} \mathrm{Th}$, which is common in most sediment types but nearly absent in sea water due to its particle-reactive behaviour. Furthermore, ${ }^{232} \mathrm{Th}$ is the starting member of the decay series and can hence not grow in from a soluble parent in the water column, as is the case for ${ }^{234} \mathrm{Th}$. Part of the ${ }^{228} \mathrm{Ra}$ that is produced through decay of ${ }^{232} \mathrm{Th}$ in the sediment diffuses back into the water column where

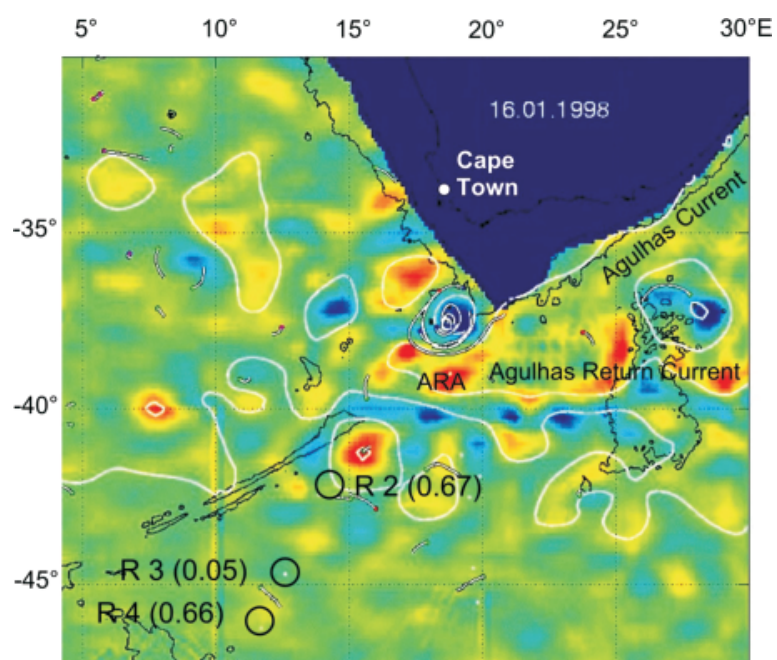

Fig. 8.1-3. Sea surface steric heights with superimposed tracks of KAPEX RAFOS floats; situation shown for 16 January 1998, coinciding with radium sampling during expedition ANT-XV/3 with RV "Polarstern". Blue colours: negative anomalies (= cyclones); yellowred colours: positive anomalies (= anticyclones, Agulhas Ring); white lines: drifter tracks; ARA: Agulhas Retroflection Area. Satellite altimetry data kindly provided and interpreted by O. Boebel, AWI. Drifter tracks are used in an animated time-series version of the figure (not shown) to follow the path of cyclones and anticyclones over time. ${ }^{228} \mathrm{Ra}$ surface water activities determined on the 15/16 January 1998 are given in brackets in dpm / $100 \mathrm{~kg}$. For ${ }^{228} \mathrm{Ra}$ sampling and methods see Hanfland (2002)

it can accumulate to high activities when in prolonged contact with sediments. This is the case above the ocean bottom or, even more pronounced, on the continental shelves. According to its relatively short half-life, the activity of ${ }^{228} \mathrm{Ra}$ decreases with distance from the source and is extremely low in the ocean interior and in open ocean surface waters.

The concept of decreasing ${ }^{228} \mathrm{Ra}$ activities in surface waters with distance to the shore has been applied in the region south of South Africa where intense mixing of subtropical and subantarctic water masses takes place: Occlusion of the retroflecting Agulhas Current generates socalled Agulhas Rings that move northwestwards into the Atlantic while perturbations in the flow of the Agulhas Current lead to the spawning of both cyclonic and anticyclonic eddies (Lutjeharms 1996; Boebel et al. 2003). In a sea surface steric height depiction of the area (Fig. 8.1-3), cyclones are represented by negative anomalies (blue colours) while anticyclones and rings are associated with positive anomalies (yellow/red colours).

The cyclones can have different origins. They either move northwards from the subantarctic region and represent Atlantic water, or originate in the course of a Natal Pulse off the coast of South Africa, and are comprised of water from the Indian Ocean. As the whole region is of great importance for interocean water exchange and represents one of the return paths of the thermohaline cir- 
culation into the Atlantic Ocean, a better distinction of the origin of the cyclones will contribute to the understanding of water exchange in that region.

Previous studies have shown that waters coming from the Antarctic zone have ${ }^{228} \mathrm{Ra}$ activities close to the detection limit (Hanfland 2002). In contrast, the Agulhas Current can be expected to pick up a strong ${ }^{228} \mathrm{Ra}$ signal while following the continental shelf edge of southern Africa.

Figure 8.1-3 displays the hydrographic situation on 16 January 1998 together with the samples taken for ${ }^{228} \mathrm{Ra}$ surface water activities within 48 hours of this snapshot. The picture reveals an anticyclonic Agulhas Ring centred around $41^{\circ} \mathrm{S}, 16^{\circ} \mathrm{E}$. Sample R2 probably gained its activity from this ring. Sample R 4 coincides with a subtropical anticyclone coming from further west. This can be deduced by backtracking the position of the associated KAPEX drifter, represented as a white line in Fig. 8.1-3, in a time-sequence of this figure (not shown).

Located between R2 and R4 is a negative sea surface anomaly where sample R3 yields a very low ${ }^{228} \mathrm{Ra}$ activity. It displays the effect of subantarctic water being entrained northwards into subtropical waters.

Based on these encouraging results, specific sampling of cyclones in the Agulhas Retroflection Area was conducted during expedition ANT-XX/2. Preliminary results indeed reveal very high ${ }^{228} \mathrm{Ra}$ activities in the surface water of one of the cyclones, suggesting an origin off the coast of South Africa. More evidence is expected to come from the analysis of complete vertical profiles that are currently being processed.

\section{${ }^{227}$ Ac As a Tracer for Upwelling of Deep Waters}

Analogous to ${ }^{228} \mathrm{Ra},{ }^{227} \mathrm{Ac}$ (half-life 21.8 years) is produced in sediments through decay of a particle-reactive mother nuclide $\left({ }^{231} \mathrm{~Pa}\right)$. In contrast to ${ }^{232} \mathrm{Th}$, the activity of ${ }^{231} \mathrm{~Pa}$ in the surface sediment is related to the depth of the overlying water column. Consequently, ${ }^{231} \mathrm{~Pa}$ activities are highest in deep-sea sediments which in turn represent the major source for ${ }^{227} \mathrm{Ac}$ released into the sea water. Excess activity of ${ }^{227} \mathrm{Ac}$ (expressed as ${ }^{227} \mathrm{Ac}_{\mathrm{ex}}$ ) over its parent nuclide ${ }^{231} \mathrm{~Pa}$ in surface waters may therefore be interpreted as evidence for rapid upwelling of deeper water masses. Figure 8.1-4 gives two examples of ${ }^{227} \mathrm{Ac}_{\mathrm{ex}}$ profiles from the Atlantic and Pacific Ocean. These show the influence of upwelling on the dissolved ${ }^{227} \mathrm{Ac}_{\mathrm{ex}}$ activities in the water column (modified after Geibert et al.2002). The location in the Southeast Pacific is characterized by little advection and does not show significant excess of ${ }^{227} \mathrm{Ac}$. Here, vertical movement of water masses is too slow to allow any ${ }^{227} \mathrm{Ac}_{\mathrm{ex}}$ signal to reach the surface. In contrast, the sampling station in the Weddell Gyre, situated in the inflow region of North Atlantic Deep water, displays high

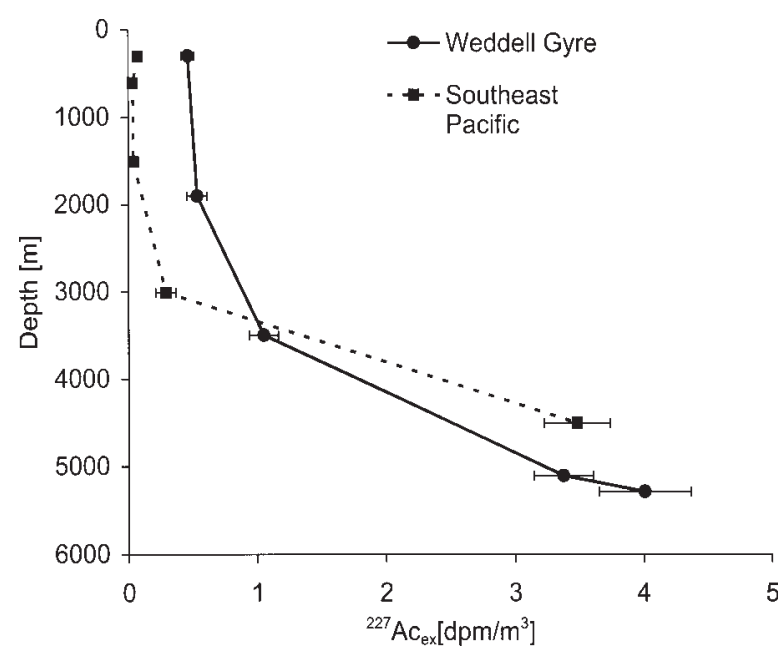

Fig. 8.1-4. ${ }^{227} \mathrm{Ac}_{\mathrm{ex}}$ profiles from two locations: Weddell Gyre (PS2579-2; $62^{\circ} 59^{\prime} \mathrm{S}, 07^{\circ} 45^{\prime} \mathrm{E}$ ) and Southeast Pacific (PS2660-7; 50 $09^{\prime} \mathrm{S}, 89^{\circ} 13^{\prime} \mathrm{E}$ ). For ${ }^{227}$ Ac sampling and methods see Geibert et al. (2002)

${ }^{227} \mathrm{Ac}_{\mathrm{ex}}$ activities in its upper part, thereby indicating a rapid upwelling of deeper water masses. Associated rates of upwelling calculated by means of ${ }^{227} \mathrm{Ac}_{\mathrm{ex}}$ were in the order of $55 \mathrm{~m} \mathrm{yr}^{-1}$. A more detailed discussion of the ${ }^{227} \mathrm{Ac}_{\mathrm{ex}}$ distribution in different hydrographic regimes can be found in Geibert et al. (2002).

\section{Conclusions}

The three examples presented were chosen to illustrate the use and applicability of naturally occurring radionuclides to process studies in the Southern Ocean. When studying particle fluxes, ${ }^{234} \mathrm{Th}$ provides a useful tool for the determination of the export of carbon to deeper water layers. This provides important constraints on whether a region serves as a sink or source for carbon dioxide. The combined analysis of ${ }^{228} \mathrm{Ra}$ and ${ }^{227} \mathrm{Ac}$ allows for a better distinction between lateral advection versus deep upwelling of water masses. Due to their specific source regions (continental shelf areas and deep-sea sediments), they provide a powerful pair of tracers to distinguish between different origins of water masses.

To summarise, the decay series are unique in that they offer a large variety of parent-daughter pairs of different reactivities, in combination with half-lives between a few days to several ten thousand years. These features make them a valuable tool in marine sciences. Specific trends or irregularities in their distribution not only confirm expectations derived from other variables, but often give an indication of hitherto unknown or unconsidered processes in a given context. With steadily improving analyzing techniques, the potential of these marine tracers can be expected to further increase in future studies. 


\section{Acknowledgments}

The authors gratefully acknowledge the efficient technical assistance of the crew of RV "Polarstern" during the sampling program. This work was supported by Deutsche Forschungsgemeinschaft (DFG grants no. RU 712/1 and GE 1118/2-2). Thanks are due to Adrian Webb and Steve Boger for proof-reading of the manuscript.

\section{References}

Boebel O, Lutjeharms J, Schmid C, Zenk W, Rossby T, Barron C (2003) The Cape Cauldron: a regime of turbulent inter-ocean exchange. Deep Sea Res II 50:57-86

Broecker WS, Peng T-H (1982) Tracers in the sea. Lamont-Doherty Geological Observatory, Palisades, New York

Coale KH, Bruland KW (1985) ${ }^{234} \mathrm{Th}:{ }^{238} \mathrm{U}$ disequilibria within the California Current. Limnol Oceanogr 30(1):22-33

Faure G (1986) Principles of isotope geology. Wiley and Sons, New York Fisher NS, Burns KA, Cherry RD, Heyraud M (1983) Accumulation and cellular distribution of ${ }^{241} \mathrm{Am},{ }^{210} \mathrm{Po}$ and ${ }^{210} \mathrm{~Pb}$ in two marine algae. Mar Ecol Prog Ser 11:233-237

Geibert W, Rutgers van der Loeff MM, Hanfland C, Dauelsberg HJ (2002) Actinium-227 as a deep-sea tracer: sources, distribution and applications. Eart Planet Sci Letters 198:147-165

Hanfland C (2002) Radium-226 and Radium-228 in the Atlantic Sector of the Southern Ocean. Rep Polar Mar Res 431:1-135

Kaufman A, Trier RM, Broecker WS (1973) Distribution of ${ }^{228} \mathrm{Ra}$ in the World Ocean. J Geophys Res 78:8827-8848

Krishnaswami S (2001) Uranium-Thorium series isotopes in ocean profiles. In: Steele JH, Thorpe SA, Turekian KK (eds) Encyclopedia of ocean sciences. Academic Press, San Diego, pp 3146-3156
Lutjeharms JRE (1996) The exchange of water between the South Indian and South Atlantic Oceans. In: Wefer G, Berger WH, Sielder G, Webb DJ (eds) The South Atlantic: present and past circulation. Springer, Berlin Heidelberg New York, pp 125-162

Moore WS (1972) Radium-228: application to thermocline mixing studies. Eart Planet Sci Letters 16:421-422

Moore WS (1992) Radionuclides of the uranium and thorium decay series in the estuarine environment. In: Ivanovitch M, Harmon RS (eds) Uranium series disequilibrium. Applications to earth, marine and environmental science. Clarendon Press, Oxford, pp 334-395

Reid DF, Moore WS, Sackett WM (1979) Temporal variation of ${ }^{228} \mathrm{Ra}$ in the near-surface gulf of Mexico. Earth Planet Sci Letters 43:227-236

Rutgers van der Loeff MM, Berger GW (1991) Scavenging and particle flux seasonal and regional variations in the Southern Ocean (Atlantic sector). Mar Chem 35:553-567

Rutgers van der Loeff MM, Moore, WS (1999) Determination of natural radioactive tracers. In: Grasshoff K, Kremling K, Ehrhardt M (eds) Methods of seawater analysis. Wiley-VCH, Weinheim, pp 365-397

Rutgers van der Loeff MM, Key RM, Scholten J, Bauch D, Michel A $(1995)^{228} \mathrm{Ra}$ as a tracer for shelf water in the Arctic Ocean. Deep Sea Res II 42:1533-1553

Rutgers van der Loeff MM, Friedrich J, Bathmann U (1997) Carbon export during the spring bloom at the Antarctic Polar Front, determined with the natural tracer ${ }^{234} \mathrm{Th}$. Deep Sea Res II 44:457-478

The Open University (1989) Seawater: Its composition, properties and behaviour. Pergamon Press, Oxford

Usbeck R, Rutgers van der Loeff MM, Hoppema M, Schlitzer R (2002) Shallow remineralization in the Weddell Gyre. Geochemistry geophysics geosystems 3(1)

Walter HJ, Geibert W, Rutgers van der Loeff MM, Fischer G, Bathmann $\mathrm{U}$ (2001) Shallow vs. deep-water scavenging of ${ }^{231} \mathrm{~Pa}$ and ${ }^{230} \mathrm{Th}$ in radionuclide enriched waters of the Atlantic sector of the Southern Ocean. Deep Sea Res I 48:471-493 
